\title{
Management Related Issues Of NGOs In District Bahawalpur, Pakistan
}

\author{
Asif Naveed Ranjha \\ Department of Social Work \\ The Islamia University of Bahawalpur \\ Muhammad Nadeemullah \\ \& \\ Muhammad Arshad \\ Department of Social Work \\ University of Karachi
}

\begin{abstract}
Increasing roles of non-government organizations in the solution of social problems and development have got importance worldwide. Thousands of NGOs provide different kind of needed services to people in Pakistan. NGOs working for the solution of social problems face various types of challenges which include specific management problems to run organizations' matters. This research was conducted to explore management related problems of NGOs in District Bahawalpur. Majority of respondent NGOs among selected sample of 116 reported that lack of financial resources not only creates but also increases management problems of local level NGOs. The research also found other internal and external management issues including lack of staff, untrained staff, no assistance and guidance of NGOs from concerned government departments, untrained executive body members, no interest of executive body members in development projects or their extra interference in NGOs matters, no ability of project designing and embezzlement in NGOs' finances. This research recommends NGOs to hire trained and hardworking staff, design better projects, manage funds in a better way and make financial matters transparent. Also, government should guide, train and fund local level NGOs considering their importance.
\end{abstract}

Keywords: NGOs, Management, Development, Communities, Services 


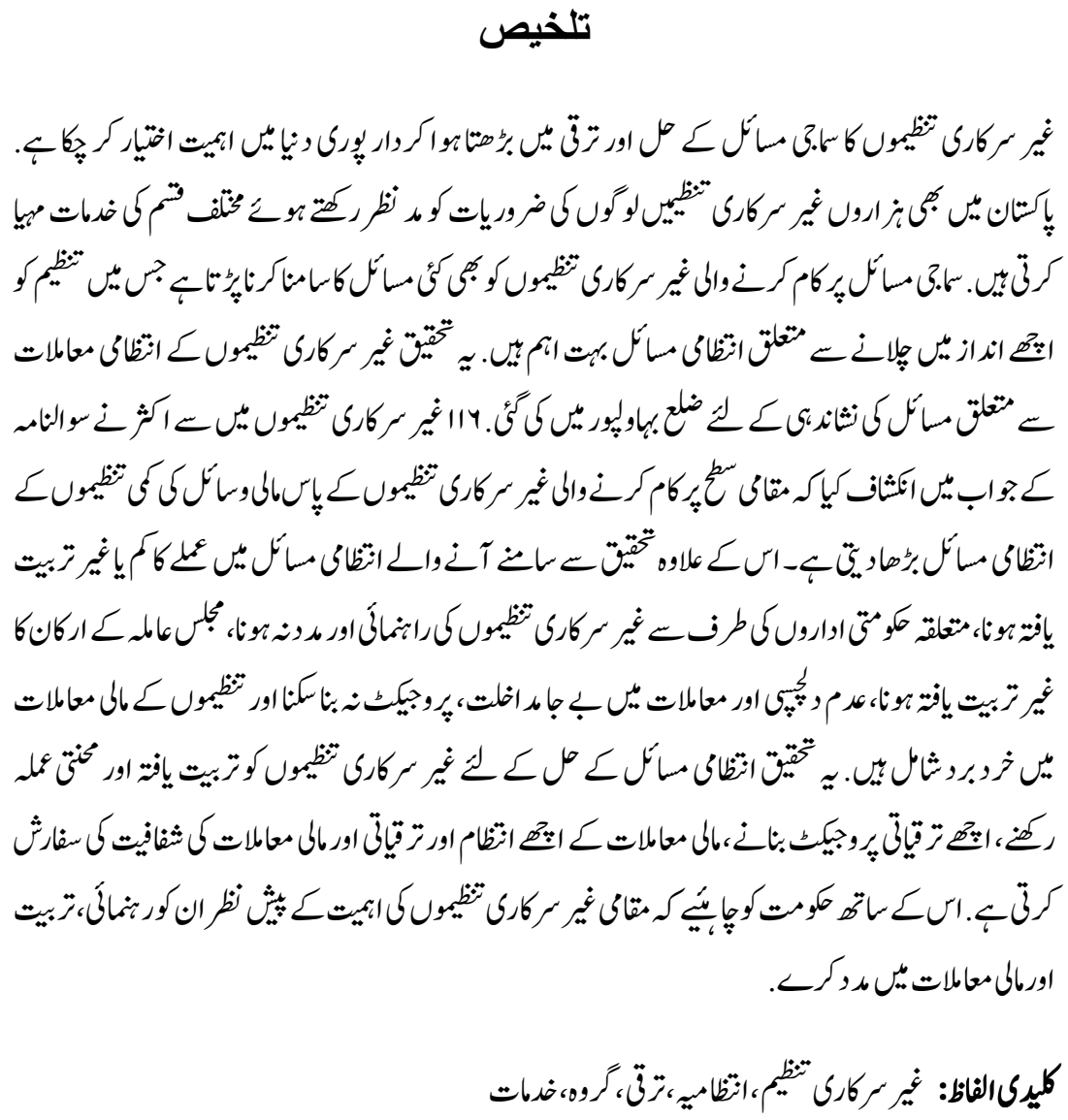

\section{Introduction}

Non-governmental organizations (NGOs) have been playing a vital role in social development sector over the last few decades. Non-profit organizations provide more effective and efficient welfare and development services at the grassroots level in comparison with government institutions in low economic countries. This sector is inevitable force in social sector worldwide (Latha \& Prabhakar, 2011). NGOs are part of the social development process as an important stakeholder especially in developing world (Roka, 2013). Communities get assistance from NGOs for many services including drinking water, basic health and education, capacity building, livelihood assistance and human rights advocacy. Multifarious services of NGOs include suffering relieve, benefits of poor, environment protection, provision of basic social services and community development (Omona \& Mukuye, 2013; Salim, Sadruddin, \& Zakus, 2012). Both, advocacy and operational organizations contribute in service delivery (Asian Development Bank, 1999) with the assistance of the government or separately. Moreover, on the 
special demands of governments, NGOs fill the remaining gaps in effective, efficient and specialized ways i.e., provision of information, strategic help, policy making, service delivery (Brinkerhoff, 2003). Therefore, the increasing role of NGOs in social sector cannot be underestimated (Omona \& Mukuye, 2013). NGOs practice different roles and functions in the respective countries (Gibelman \& Gelman, 2001) which certainly depend on existing conditions and the needs of local communities. There are different kinds of organizations classified on the basis of geographical coverage, thematic scope, practices and religion. The number and size of NGOs got rapid growth during last two, three decades (Roka, 2013). Government roles got changed due to globalization and democratization specially in developing world during the last three decades and NGOs got space to work and increase in number and power where governments cannot provide or do not want to provide services (Omona \& Mukuye, 2013). In Pakistan, revival of democracy, privatization, globalization, contact with international organizations and lack of government funds for social development, enhanced growth rate of NGOs during 1990s (Pasha, Pasha, \& Iqbal, 2002). A large number of local, national, international, advocacy, operational, religious and secular organizations works in Pakistan. These organization provide various service including education, health and community development (Sadruddin, 2012). In majority cases, NGOs offer those needed services which benefit individuals and communities (Jones \& Mucha, 2014). Every NGO designs projects and activities according to its nature, scope, potential and available resources.

NGOs have to manage all matters related to social development for better service delivery and self-survival. That management includes human, financial and material resources involved in NGOs or their specific development projects. Donors take interest in funding to NGOs due to effective and efficient working and their reach to poor communities at grassroots level (Omona \& Mukuye, 2013; Salim et al., 2012). Organizational effectiveness is hard to define and is also disputed in the practices of NGOs (Tassie, Murray, \& Cutt, 1998). Over the last three decades, success and failure of NGOs has been focussed in the private social development sector (Helmig, Ingerfurth, \& Pinz, 2014). NGOs are capable of better service delivery in local communities when manage internal affairs in satisfactory ways. This is unfortunate that many NGOs are inactive or dead in Pakistan due to which NGO sector is questioned and blamed in some matters. The major reason behind non-functional organizations could be weak management. There are various management related issues effecting routine practices or particular development projects of NGOs. These issues start from NGOs' registration. Registration process requirements include verification of office, members and finances. Registration of NGOs ensures legal status and makes them 
eligible to work at grassroots level and for funding from government or private donors. This phenomenon exists worldwide that legislative authorities have concerns about NGOs governance and accountability regarding reports provided to NGOs (Reheul, Van Caneghem, \& Verbruggen, 2014). As NGOs, local level organizations depend on funding from government, private donors and volunteers, there is a need to improve check and balance system which is possible through suitable NGO management practices. There are different legislations for NGOs' registration (Ismail, 2002) processed by different government departments in Pakistan, which guide scope and other working boundaries for NGOs. In many cases, people get registration of NGOs not for welfare or development but for other purposes. NGOs get legal protection and tax relaxation on the basis of being charity oriented organizations in many countries (Cordery \& Morgan, 2013). Many organizations get registration for relaxation purpose and become inactive or dead because of having no or lack of management. In 1996, NGOs resisted an attempt by the government regarding NGOs registration to make them more functional (Iqbal, Khan, \& Javed, 2004). NGOs and government are not on same page. NGOs consider monitoring and control system by state as an exploitation (Gondal, 2012).

Most NGOs have low or no staff. NGOs face various challenges regarding commitment, discipline, trainings, authorities, conflicts and financial embezzlement of staff. Often, NGOs cannot achieve target objectives due to lack of staff and staff training, mismanagement or embezzlement (Salim et al., 2012). Conflicts between hired staff and members effect management of NGOs and their development projects Increase in NGOs number has increased funding applications in donor offices. This competition puts extra pressure and workload on staff causing management issues (Salim et al., 2012). Extra efforts and resources are required to achieve the targets which demand high commitment from staff. Small scale NGOs cannot assure their staff for long term job which keeps staff members under stress. These organizations, mostly rely on funding from international donors. Important factors to influence staff for better results in NGOs include rewards, justice, supervisory assistance, trainings, job guarantee and conditions. Human resource management is vital for NGOs (Batti, 2014) so that they could enhance their effectiveness and efficiency and could ensure donor's priorities, better service delivery and accountability (Ridder, Piening, \& Baluch, 2012). In developing countries, staff members have to work according to availability and convenience of people in community development projects with extra commitments for continuity of operations (Salim et al., 2012). 
Financial matter is very critical in NGOs' management and service delivery in communities. Often, NGOs failures are because of low or no finances. Mismanagement in budgeting cause different embezzlement blames on NGOs. No strategies for proper funds utilization and embezzlement matters effect overall internal and external management of NGOs. Standing of any NGO depends on its check and balance, transparent work, legality, networking and usefulness (Omona $\&$ Mukuye, 2013). Stories of corruption and scandals regarding the working of NGOs also exist with the increased influence of the NGO sector (Williams \& Taylor, 2013). NGOs are focused by governments, media, academic world and watchdogs due to questions raised on the accountability of NGOs. Besides that, small and local level organizations face difficulties in their survival when do not get funding from government or private donors.

The internal culture of NGOs becomes their strength or weakness, productivity or non-productivity and efficiency or inefficiency (Shiva \& Suar, 2012). Membership and manipulation issues within organization cause more management related problems (Pijl \& Sminia, 2004). The internal operations of any organization are very critical and internal problems, differences and inconsistencies have effects. Executive body members are considered founder and very sincere in any organizations. In many organizations, their role is criticized regarding their conduct. According to Shiva and Suar (2012), one man show is practiced in most of the NGOs and staff members assist and obey a single authority. Sometimes, they are blamed to misuse authorities in management matters. It is fact that organizations are answerable to executive body members about working and these members normally do not influence working policies of NGOs (Lansley, 1996). Commonly, these members assist NGOs on funding, legitimacy and voluntary matters. Interference by these members could be problematic for practices of running staff in organizations. Most NGOs do not conduct executive body election as per the given schedule guided by registration rules. In addition, management gets effected due to conflicts among body members, lack of trainings, political or religious affiliation, unnecessary involvement in organization matters and involvement in the embezzlement.

A very limited number of NGOs have qualified, trained and committed staff for project designing, implementation and management. Even, some organizations pay for project designing to private consultants because of lacking project designers in their own setup. Most of local level organizations cannot design development project due to no guidance from concerned government departments. Resultantly, NGOs without projects have various challenges to manage field, even their office sometimes. NGOs management issues also include no availability or 
lack of material resources. Small scale organizations have no proper offices, office equipment, furniture and transportation for movement in local communities. Many NGOs do not submit progress reports timely (Shiva \& Suar, 2012). Some of them are not in a position to prepare their progress or audit reports due to lack of staff or material resources. NGOs design development projects in a rush to get funding and do not involve other partner stakeholders which effects projects at any stage later on. International donor agencies may delay, minimize and withdraw funds in cases of failure of NGOs to achieve target objectives (Salim et al., 2012). Local level NGOs' operations get damaged due to delay, reduction or withdrawal of funding from donors.

Presently, NGOs face different type of issues (Argandona, 2007). Unfortunately, there are gaps in factual findings regarding NGOs working and their issues in Pakistan. This research focussed on an unattended area of NGOs' issues regarding management. The research was conducted in District Bahawalpur. Local level NGOs (371) registered with the Department of Social Welfare \& Bait ul Mal were included in the study. Major objectives of the research were to explore issues related to guidance and training from the Department of Social Welfare \& Bait ul Mal, NGOs' staff, staff performance and executive body members, financial matters and material resources. The results of research would be helpful for policy makers, NGOs, donors and academicians in understanding nature and causes of NGOs' management issues.

\section{Methods}

This survey research was conducted in District Bahawalpur with aim to know about major issues which effect or influence the management of NGOs. Human universe included members of NGOs registered with the Department of Social Welfare \& Bait ul Mal, Punjab under 'The Voluntary Social Welfare Agencies (Registration and Control) Ordinance, 1961. Total 371 NGOs are registered with 6 community development project offices (Department of Social Welfare \& Bait ul Mal) in District Bahawalpur. Respondent NGOs were selected through systematic sampling and 35 percent proportion was selected from each community development project office. Questionnaires were delivered to total 129 selected respondents and 116 of them responded. Data was processed through Statistical Package for Social Sciences (SPSS). Results have been presented in multiple response tables. 


\section{Results}

Total 116 participants responded out of 129 selected for research. The results have been presented in tables with total responses given by 116 participants. Number of responses against every query with percentage of respondents makes results easy to understand.

Table: 1

Service Areas of Organizations

\begin{tabular}{|l|c|c|}
\hline Service Areas of Organizations & $\begin{array}{c}\text { Number of } \\
\text { responses }\end{array}$ & $\begin{array}{c}\text { Percent } \\
(\mathbf{n = 1 1 6})\end{array}$ \\
\hline Education & 67 & 58 \\
\hline Health & 51 & 44 \\
\hline Child welfare & 45 & 39 \\
\hline Women welfare & 62 & 53 \\
\hline Disable welfare & 11 & 9 \\
\hline Youth welfare & 34 & 29 \\
\hline Old age welfare & 8 & 7 \\
\hline Religious services & 15 & 13 \\
\hline Sports and recreation & 4 & 3 \\
\hline Population welfare & 5 & 4 \\
\hline Community development & 34 & 29 \\
\hline Cultural promotion & 3 & 3 \\
\hline Missing & 2 & 2 \\
\hline Total & $\mathbf{3 4 1}$ & \\
\hline
\end{tabular}

Table No. 1 shows the service areas of NGOs. Responses given by respondents indicate that many NGOs work in more than one field. The majority of local level NGOs is engaged in education related services $(58 \%)$ and women welfare services (53\%). Health is also seen as important thematic area for these organizations $(44 \%)$. Many respondent organizations render welfare services for children (39\%), youth (29\%) and community development (29\%). Some are providing services for disables (9\%) and religious purposes (13\%). Other NGOs 
deliver for old age people, population welfare, sports and recreation and cultural promotion.

Table: 2

Nature of NGOs' Management Problems Caused by Department of Social Welfare \& Bait ul Mal

\begin{tabular}{|l|c|c|}
\hline Nature of NGOs' Management Problems & $\begin{array}{c}\text { Number of } \\
\text { responses }\end{array}$ & $\begin{array}{c}\text { Percent } \\
\text { (n=116) }\end{array}$ \\
\hline NGOs' registration related problems & 21 & 18 \\
\hline No guidance for progress reports & 45 & 39 \\
\hline No guidance for audit reports & 56 & 48 \\
\hline No provision of proper and needed trainings & 61 & 53 \\
\hline $\begin{array}{l}\text { No proper guidance about welfare and } \\
\text { development }\end{array}$ & 66 & 38 \\
\hline Strict checks on organization & 44 & 6 \\
\hline No problem & 7 & 6 \\
\hline Missing & $\mathbf{3 0 7}$ & \\
\hline Total & & \\
\hline
\end{tabular}

Table No. 2 presents responses about NGOs' management issues related to the Department of Social Welfare \& Bait ul Mal. Considerable majority (57\%) reports that NGOs do not get proper guidance on welfare and development from the registration authority which creates management problems. More than half respondents mention that the Department of Social Welfare \& Bait ul Mal do not provide them needed trainings to run NGOs matters (53\%). Almost half respondents (48\%) blame the Department of Social Welfare \& Bait ul Mal for not guiding about audit reports which effect management. More than one third (39\% respondents) report that they do not get guideline for progress reports. Many NGOs (38\%) face strict pressures and checks by the Department of Social Welfare $\&$ Bait ul Mal. Some NGOs also face issues with registration, which indirectly creates management problems. Seven respondents did not respond. 
Table: 3

Nature of NGOs' Management Problems Related to Staff

\begin{tabular}{|l|c|c|}
\hline $\begin{array}{l}\text { Nature of NGOs' Management Problems } \\
\text { related to Staff }\end{array}$ & $\begin{array}{c}\text { Number of } \\
\text { responses }\end{array}$ & $\begin{array}{c}\text { Percent } \\
(\mathbf{n = 1 1 6})\end{array}$ \\
\hline Lack of staff & 51 & 44 \\
\hline Untrained staff & 65 & 56 \\
\hline Lack of hard work & 27 & 23 \\
\hline Conflicts among staff & 34 & 29 \\
\hline Conflicts between staff and board members & 30 & 26 \\
\hline Lack of discipline & 45 & 39 \\
\hline Involvement in financial embezzlement & 19 & 16 \\
\hline Staff with no authorities & 29 & 25 \\
\hline No problem & 15 & 13 \\
\hline Missing & 2 & 2 \\
\hline Total & $\mathbf{3 1 7}$ & \\
\hline
\end{tabular}

Staff members play very critical role in internal management matters. Table No. 3 shows responses of NGOs' representatives about staff related issues. The majority of respondents pointed out untrained staff as a major reason for management issues in local level NGOs $(56 \%)$. They also report lack of staff as the second major factor effecting NGOs' management (44\%). More than one third respondents $(39 \%)$ consider indiscipline of staff members as reason for mismanagement. Conflicts among staff members (29\%) and between staff and board members (26\%) effect NGOs' management and operations. Staff members with no or lack of authorities cannot manage NGOs affairs $(25 \%)$ on the other hand, lack of hard work from staff effects management matters $(23 \%)$. Results also show financial embezzlement by staff members as a management issue $(16 \%)$. Fifteen respondents $(13 \%)$ do not report any management issue related to staff. 
Table: 4

Nature of NGOs' Management Problems Related to Executive Body Members

\begin{tabular}{|l|c|c|}
\hline $\begin{array}{l}\text { Nature of NGOs' Management Problems } \\
\text { related to Executive Body Members }\end{array}$ & $\begin{array}{c}\text { Number of } \\
\text { responses }\end{array}$ & $\begin{array}{c}\text { Percent } \\
\text { (n=116) }\end{array}$ \\
\hline No Regular body elections & 31 & 27 \\
\hline Conflicts among members & 34 & 29 \\
\hline Irregular or no executive body meetings & 52 & 45 \\
\hline Untrained members & 51 & 44 \\
\hline Political/Religious/ affiliation of members & 26 & 22 \\
\hline $\begin{array}{l}\text { Interference of members in matters of } \\
\text { working staff }\end{array}$ & 31 & 27 \\
\hline Involvement in financial embezzlement & 5 & 4 \\
\hline No problem & 11 & 9 \\
\hline Missing & 5 & 4 \\
\hline Total & $\mathbf{2 4 6}$ & \\
\hline
\end{tabular}

Table No. 4 informs about NGOs management issues caused by executive members. Multiple responses were given by the respondents. The majority of respondents $(45 \%)$ points out irregular or even no meetings of executive body members. This makes NGOs internal management weak. Executive members are untrained regarding NGOs matters and social development which effects NGOs' administration (44\%). Another issue is conflict among board members (29\%). Respondents find interference of executive members in working of staff (27\%) and also report irregular executive body elections (27\%). The members do have political or religious affiliations (22\%). Five (5) respondents admitted involvement of board members in financial embezzlement and 11 respondents do not see any problem related to executive body members and five (5) did not answer. 
Table: 5

Financial Problems

\begin{tabular}{|l|c|c|}
\hline Financial Problems & $\begin{array}{c}\text { Number of } \\
\text { responses }\end{array}$ & $\begin{array}{c}\text { Percent } \\
\text { (n=116) }\end{array}$ \\
\hline No regular membership fee submission & 29 & 25 \\
\hline Submission of less membership fee & 46 & 40 \\
\hline $\begin{array}{l}\text { No collection of funds from voluntary } \\
\text { sources }\end{array}$ & 65 & 56 \\
\hline No funding from government for projects & 71 & 61 \\
\hline Improper utilization of NGOs' funds & 26 & 23 \\
\hline Financial embezzlement & 27 & 3 \\
\hline No problem & 4 & 1 \\
\hline Missing & 1 & $\mathbf{2 6 9}$ \\
\hline Total & & 23 \\
\hline
\end{tabular}

Finance related matters are taken very seriously in NGO management. Table No. 5 reveals facts about finance related issues of respondent organizations. Majority of respondents blame government for their financial problems $(61 \%)$. They consider that no funding from government side effects financial management of NGOs. More than half of the respondents $(56 \%)$ disclose that NGOs do not get funding from volunteer sources which makes them weak financially. Members pay less than the required amount of membership fee (40\%) and some do not pay regularly (25\%). Financial embezzlement is also one of considerable issues related to management (23\%). Funds are not utilized properly, which effect overall management (22\% respondents). 
Table: 6

Problems Related to Project Designing

\begin{tabular}{|l|c|c|}
\hline Problems related to Project Designing & $\begin{array}{c}\text { Number of } \\
\text { responses }\end{array}$ & $\begin{array}{c}\text { Percent } \\
(\mathbf{n = 1 1 6})\end{array}$ \\
\hline $\begin{array}{l}\text { No guidance from Department of Social } \\
\text { Welfare }\end{array}$ & 34 & 29 \\
\hline No interest in project designing & 39 & 34 \\
\hline Untrained staff for project designing & 72 & 62 \\
\hline $\begin{array}{l}\text { Extra spending on buying projects from } \\
\text { private consultants }\end{array}$ & 32 & 28 \\
\hline No problem & 17 & 15 \\
\hline Missing & 5 & 4 \\
\hline Total & $\mathbf{1 9 9}$ & \\
\hline
\end{tabular}

Multiple responses were given by respondents about different issues related to project design. According to Table No. 6, nearly two third respondents (62\%) blame untrained staff for not designing proper community development projects. Certainly, no or lack of projects creates management issues in NGOs. More than one third respondents (34\%) admit no interest of their NGOs in project designing. Nearly one third respondents (29\%) blame the Department Social Welfare \& bait ul Mal for providing no guidance for project designing. Many respondents disclose that NGOs buy projects from private consultants instead of designing projects (28\%). Seventeen (17) respondents did not see any problems related to project designing. 
Table: 7

Problems Related to Infrastructure and Equipment

\begin{tabular}{|l|c|c|}
\hline $\begin{array}{l}\text { Problems related to Infrastructure and } \\
\text { Equipment }\end{array}$ & $\begin{array}{c}\text { Number of } \\
\text { responses }\end{array}$ & $\begin{array}{c}\text { Percent } \\
(\mathbf{n = 1 1 6})\end{array}$ \\
\hline No proper office & 64 & 55 \\
\hline No or improper of office furniture & 46 & 40 \\
\hline No or lack of office equipment & 57 & 49 \\
\hline No own transport for field movement & 67 & 58 \\
\hline No problem & 14 & 12 \\
\hline Missing & 1 & 1 \\
\hline Total & $\mathbf{2 4 9}$ & \\
\hline
\end{tabular}

Table No. 7 shows the results about problems faced by NGOs regarding infrastructure and equipment. The majority of respondents $(58 \%)$ consider no availability of transport as major infrastructure and equipment problem effecting NGOs management. More than half of the respondents (55\%) report improper offices as a major management issue. Half of respondents (49\%) find that no or lack of office equipment creates management problems. More than one third mentioned lack of proper furniture in offices (40\%). Fourteen (14) respondents do not find problems.

\section{Discussions}

All above mentioned results regarding NGOs' management issues are worth noting. It seems very encouraging and positive trend that local level NGOs render their welfare and development services in various needed fields i.e., education, women welfare, health, child welfare, youth welfare, community development, religion, disable welfare, old age welfare, population welfare, sports and recreation and cultural promotion. Here, multifarious functions of local NGOs seen as an agreement with NGOs functions in other countries mentioned by Omona and Mukuye (2013) and Salim et al. (2012).

The results of this research find various attention demanding issues regarding NGOs' management especially at local level. NGOs registered with the Department of Social Welfare \& Bait ul Mal lack proper guidance from the registration authority about welfare and development. This shortcoming directly or indirectly effects management of these local level NGOs. Further, these organizations need proper trainings for good footing to serve better in local communities. They do not get needed trainings and guidance about preparation of 
progress and audit reports. In case of no expertise in report writing and audit, NGOs automatically face mismanagement issues. Ultimately, stories about fake progress and embezzlement come on the scene. Here, alone government or registration authorities are not responsible for NGOs issues related to management. NGOs could also be responsible in their management problems. Department of Social Welfare \& Bait ul Mal as government authority can monitor and control NGOs' working, but they should provide proper guidance as per needs of these small scale organizations.

Besides the government's responsibilities, working of staff in NGOs is not satisfactory as explored in research. Their staff is untrained and even a shortage of staff is reported. Lack of staff and training demand more hard work and discipline from working staff. Unfortunately, the results show indiscipline, conflicts and lack of hard work in working staff. All these issues lead an NGO toward mismanagement. How could any organization expect good results in its management when staff members are with low or no authorities to do jobs? Some NGOs report financial embezzlement by staff members which could damage recognition of those organizations. This finding seems an agreement with Williams and Taylor (2013) who talks about stories of corruption and scandals regarding NGOs' working. No doubt, management body or executive body members are very important. Results show some weaknesses and lacks regarding the role of the executive members of NGOs which effect management matters. These members are reported irregular or absent from meetings and also are untrained to deal with welfare or development projects. They have conflicts among them. Their interference in matters of hired staff makes NGOs' management issues more worst. The results agree with Shiva and Suar (2012) that mostly NGOs do have one man show and all other staff has to obey him.

It is worth noting that NGOs do not get funding from government and volunteer sources which lead them towards inactiveness or mismanagement. One reason for the increase in the number of NGOs is to win funding from donors (Salim et al., 2012). If they do not get funding, they are not able to run projects or even survive. NGOs' management issues get increased when members do not pay membership fees or pay less. The results are very clear about improper utilization of funds and financial embezzlement, which is a major sign of mismanagement. Untrained staff and shortage put extra burden on existing staff member and they are not in the position to design development projects. On the other hand, NGOs' management also lacks project designing interest. No NGO could survive in social development sector without project designing and implementation. No project means no management. The results report another horrible management related issue that some NGOs pay to private consultants for preparation of development projects. In case of purchasing projects, NGOs would not be able to manage those projects and NGOs' matters in a professional and better way. Small scale NGOs 
lack proper transportation for field movement, proper offices for work, office equipment and furniture. In such conditions, these local level NGOs have to face various management challenges related to office and project management.

\section{Conclusions and Recommendations}

Although, NGOs serve in many areas in local communities, but the majority of local level NGOs faces different management issues to run their matters. The research concludes that NGOs lack government guidance and proper trainings necessary for management. Staff is short and untrained and NGOs cannot manage their jobs with untrained, less committed, indiscipline and weak staff. Conflicts and involvement of staff and members in financial embezzlement make NGOs more weak and doubtful. Failure in project designing and implementation shows poor management of NGOs. Improper office, lack of office equipment and lack of transportation also effect smooth and better working of NGOs.

The results recommend that NGOs need to remain in contact and coordination with concerned government departments for required guidance and trainings. They need to hire trained, hardworking, honest and sufficient staff for better management and performance. NGOs should design development project on their own and should keep all matters very transparent. On the other hand, the government needs to guide, train, assist and provide finances to small scale NGOs for bringing better changes in organizations and communities overall.

\section{References}

Argandona, A. (2007). Ethical Management Systems for Not-for-Profit Organizations Working Paper Wp no 693. Barcelona, Spain: University of Navarra.

Asian Development Bank. (1999). A Study of NGOs-Pakistan Retrieved 12 January 2105, from https://www.google.co.uk/?gws_rd=ssl\#q=A+Study+ of+NGOs+in+Pakistan\%2C+ADB\%2C+1999

Batti, R. C. (2014). Human Resource Management Challenges Facing Local NGOs. Humanities and Social Sciences, vol. 2:4, pp.87-95.

Brinkerhoff, J. (2003). Donor-Funded Government-NGO Partnership for Public Service Improvement: Cases from India and Pakistan. VOLUNTAS: International Journal of Voluntary and Nonprofit Organizations, vol.14:1, pp.105-122. 
Cordery, C., \& Morgan, G. (2013). Special Issue on Charity Accounting, Reporting and Regulation. VOLUNTAS: International Journal of Voluntary and Nonprofit Organizations, vol.24:3, pp.757-759.

Gibelman, M., \& Gelman, S. (2001). Very Public Scandals: Nongovernmental Organizations in Trouble. VOLUNTAS: International Journal of Voluntary and Nonprofit Organizations, vol.12:1, pp.49-66.

Gondal, I. A. (2012). Role of Ngo's in Pakistan: An Overview. Al-Adwa, vol.38:27.

Helmig, B., Ingerfurth, S., \& Pinz, A. (2014). Success and Failure of Nonprofit Organizations: Theoretical Foundations, Empirical Evidence, and Future Research. VOLUNTAS: International Journal of Voluntary and Nonprofit Organizations, vol.25:6, pp.1509-1538.

Iqbal, M. A., Khan, H., \& Javed, S. (2004). Nonprofit Sector in Pakistan: Historical Background SPDC Working Paper No. 4. Karachi: Social Policy and Development Centre and Center for Civil Society, Johns Hopkins University, USA.

Ismail, Z. H. (2002). Law and the Nonprofit Sector in Pakistan. SPDC Working Paper No. 3: Social Policy and Development Cetnre and Center for Civil Society, Johns Hopkins University, USA.

Jones, K., \& Mucha, L. (2014). Sustainability Assessment and Reporting for Nonprofit Organizations: Accountability "for the Public Good". VOLUNTAS: International Journal of Voluntary and Nonprofit Organizations, vol.25:6, pp.1465-1482.

Lansley, J. (1996). Membership Participation and Ideology in Large Voluntary Organisations: The Case of the National Trust. VOLUNTAS: International Journal of Voluntary and Nonprofit Organizations, vol.7:3, pp.221-240.

Latha, K. L., \& Prabhakar, K. (2011). Non-government Organizations: Problems \& Remedies in India. Serbian Journal of Management, vol.6:1, pp.109121.

Omona, J., \& Mukuye, R. (2013). Problems of Credibility of NGOs in Uganda: Implications for Theory and Practice. VOLUNTAS: International Journal of Voluntary and Nonprofit Organizations, vol.24:2, pp.311-334. 
Pasha, A. G., Pasha, H. A., \& Iqbal, M. A. (2002). Nonprofit Sector in Pakistan: Government Policy and Future Issues. SPDC Working Paper No. 2. Karachi: Social Policy and Development Centre and Center for Civil Society, Johns Hopkins University, USA.

Pijl, K., \& Sminia, H. (2004). Strategic Management of Public Interest Organizations. VOLUNTAS: International Journal of Voluntary and Nonprofit Organizations, vol.15:2, pp.137-155.

Reheul, A.-M., Van Caneghem, T., \& Verbruggen, S. (2014). Financial Reporting Lags in the Non-profit Sector: An Empirical Analysis. VOLUNTAS: International Journal of Voluntary and Nonprofit Organizations, vol.25:2, pp.352-377.

Ridder, H.-G., Piening, E., \& Baluch, A. (2012). The Third Way Reconfigured: How and Why Nonprofit Organizations are Shifting Their Human Resource Management. VOLUNTAS: International Journal of Voluntary and Nonprofit Organizations, vol.23:3, pp.605-635.

Roka, K. (2013). Jude L. Fernando: The Political Economy of NGOs: State Formation in Sri Lanka and Bangladesh. VOLUNTAS: International Journal of Voluntary and Nonprofit Organizations, vol.24:3, pp.911-913.

Sadruddin, M. M. (2012). Study on the Role of Media, NGOs and Civil Society in Promoting Pluralism in Pakistan. The Dialogue, vol.7:2, pp.59-77.

Salim, L., Sadruddin, S., \& Zakus, D. (2012). Organizational Commitment in a Health NGO in Pakistan. VOLUNTAS: International Journal of Voluntary and Nonprofit Organizations, vol.23:3, pp.584-604.

Shiva, M. S. A., \& Suar, D. (2012). Transformational Leadership, Organizational Culture, Organizational Effectiveness, and Programme Outcomes in NonGovernmental Organizations. VOLUNTAS: International Journal of Voluntary and Nonprofit Organizations, vol.23:3, pp.684-710.

Tassie, B., Murray, V., \& Cutt, J. (1998). Evaluating Social Service Agencies: Fuzzy Pictures of Organizational Effectiveness. VOLUNTAS: International Journal of Voluntary and Nonprofit Organizations, vol.9:1, pp.59-79.

Williams, A., \& Taylor, J. (2013). Resolving Accountability Ambiguity in Nonprofit Organizations. VOLUNTAS: International Journal of Voluntary and Nonprofit Organizations, vol.24:3, pp.559-580. 
Asif Naveed Ranjha is Lecturer in the Department of Social Work, The Islamia University of Bahawalpur.

Dr. Muhammad Nadeemullah is Assistant Professor in the Department of Social Work, University of Karachi.

Dr. Muhammad Arshad is Assistant Professor in the Department of Social Work, University of Karachi. 